Selcuk Journal of Agriculture and Food Sciences

http://sjafs.selcuk.edu.tr/sjafs/index

Review Article
SJAFS

(2021) 35 (1), 65-70

e-ISSN: $2458-8377$

DOI:10.15316/SJAFS.2020.230

\title{
From Climate Change and Biodiversity Towards Sustainable Agriculture
}

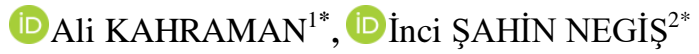 \\ ${ }^{1}$ Selçuk University, Faculty of Agriculture, Department of Field Crops, Konya, Turkey \\ ${ }^{2}$ Selçuk University, Faculty of Agriculture, Department of Plant Protection, Konya, Turkey
}

\begin{tabular}{|c|c|}
\hline ARTICLE INFO & ABSTRACT \\
\hline $\begin{array}{l}\text { Article history: } \\
\text { Received date: } 15.01 .2021 \\
\text { Accepted date: } 24.03 .2021\end{array}$ & $\begin{array}{l}\text { Agriculture is part of both problem and solution of climatic change besides } \\
\text { being one of the most important entire global financial systems. Human pres- } \\
\text { sure on climate is changing quite faster than ever and predicted irreversible }\end{array}$ \\
\hline $\begin{array}{l}\text { Edited by: } \\
\text { Duran YAVUZ; Selcuk University, } \\
\text { Turkey }\end{array}$ & $\begin{array}{l}\text { on nature, atmosphere, soil, and every single component of the organisms. } \\
\text { From this perspective, all the living organisms are threatened by climatic ef- } \\
\text { fects. The worst affects and extinction have been started to be seen on many } \\
\text { endemic species. Climate and biodiversity are under destructive effects of }\end{array}$ \\
\hline $\begin{array}{l}\text { Keywords: } \\
\text { Agronomic impacts } \\
\text { Biosecurity } \\
\text { Environmental sustainability } \\
\text { Global warming } \\
\text { Nature education }\end{array}$ & $\begin{array}{l}\text { well by the main effects on human health, extinction of species, narrowing on } \\
\text { living space, disruption of life balance, changes in climate, ecological prob- } \\
\text { lems, natural disasters, exhaustion of natural resources, loss of efficiency and } \\
\text { yield, etc. disasters which are tending to the term of sustainability of life. } \\
\text { Threats to environment might be decreased by support of governments but } \\
\text { actually possible by volunteering of public in national and global scales. Pre- } \\
\text { sent paper reviews the highlights about current statues of climatic changes and } \\
\text { threats on biodiversity by summarizing some important issues. Climate- } \\
\text { friendly management strategies are required to decrease the agricultural } \mathrm{N}_{2} \mathrm{O} \\
\text { emissions, increasing of people (especially for farmers) awareness, pay atten- } \\
\text { tion for sustainable agriculture systems, composting of organic wastes, support } \\
\text { to carbon sequestration, well planned grazing of livestock, using of renewable } \\
\text { green and effective energy, government investments for protection of biodiver- } \\
\text { sity. It is also recommended that; nature education for everyone is an important } \\
\text { issue and essential for solving the problems. Giving information to human } \\
\text { about the nature should be well-planned by governments and every single } \\
\text { person should be aware the global importance of the topic. }\end{array}$ \\
\hline
\end{tabular}

\section{Introduction}

Ecosystems include biodiversity while number of species is higher in the tropics and some other localized areas and usually lower in polar areas (WCMC, 1992). Amount of damage to biodiversity is related with altitude, climate, soil, latitude and interactions among species (Pidwirny, 2006).

See by the history of world, it is fair that climate changes over time. Similarly, patterns of biodiversity also change depending on climate (NASA, 2011), like eight cycles of ice enlargement through the last 750000 years in total (Williams, 2009) while the last ice age realized around 7000 years before and that is the time of human civilization (Brooks, 2004). Likewise, climatic changes take very big carefulness due to it is

\footnotetext{
* Corresponding author email: incisahin@selcuk.edu.tr
}

estimated to be induced by human efforts and unexpected climate changing ratios during the last 1300 years (Ramaswamy et al., 2006; Solomon et al., 2007). Changes in climate are welded by many factors that may be listed as following (Beton, 2011); sea level rise about $17 \mathrm{~cm}$ in the last century (Church and White, 2006), global temperature rise (Allison et al., 2011) warming oceans about $16 \times 1022 \mathrm{~J}\left(8.425 \times 1019^{\circ} \mathrm{C}\right)$ in the top 700 metersfrom 1969 to 2008 (Levitus et al., 2009), shrinking ice sheets by 150 to $250 \mathrm{~km}^{3}$ of ice lost in Greenland from 2002 to 2006 and $152 \mathrm{~km}^{3}$ lost on Antarctica from 2002 to 2005 (Velicogna and Wahr, 2005; NASA, 2011), the decline of Arctic sea ice (Polyak et al., 2010), glacial retreat including Africa, Andes, Alaska, Alps, Himalayas, Rockies (NSIDC, 2011; WGMS, 2011), extreme climatic events since 1950 (NOAA, 2011), ocean acidification; since 1750s welded by industrial revolution by increasing carbon dioxide content rate around 2 billion tons per year 
(NASA, 2011), 30\% higher acidity in the ocean (Sabine et al., 2004). On the other hand, plant breeders give a lot of effort to increasing of yield and quality (Toker et al., 2019; Sari et al., 2020) and on this point, biodiversity is indispensible factor to succeed.

Consciousness of human about sustainability of life is very important not only local scale but also important for global scale. Changes in climate, environmental pollution, extinction of species, threats on biodiversity, reduction of productivity and quality, difficulty of breeding plants to adapt for a long time are closely relevant to health, hunger, malnutrition, welfare and the other components of mankind. Present paper describes some approaches for factors of global climate changes and interactions with biodiversity.

\subsection{Climate and Biodiversity}

Biodiversity defines the living nature. Land, sea and other aqua ecosystems are components of the ecology. Biological diversity focuses on the several biotic and abiotic factors by views of their living area, changes in life statues, their relations with other living and nonliving organisms, changes depended on place and time, genes, species, ecosystems and all functions (Graham et al., 2004). Genetic diversity is affected by (Çepel, 1997); natural factors (climate, soil, landforms), paleogeography (shift of continents, climatic changes) and biologic factors (human, animal and plants) while it occurs by (Schulze and Mooney, 1994); geographic region, life time, migration, providing of the demands for life (food, water, genetic

temperature etc.) which remind and/or closely depended to climatic factors,.

Interdependent statues of climate and biodiversity give rise to certain harmful effects of climate on species especially for their characteristics and dispersions. Some of the various predicted effects are listed; changes in number of species, increasing of habitat disruption, changes in lifecycles (Blaustein et al., 2010), increasing of infectious diseases spreading by several agents (Pounds et al., 2006; Bosch et al., 2007; Wake, 2007)that may be also including Coronavirus (Covid-19) already caused many deaths and infectious pandemic diseases recorded over the world such as Plague, Smallpox, Measles, Yellow fever, Cholera, HIV, AIDS, Ebola, Sars and Mers (Pitlik, 2020; WHO, 2021)

Changes in climate have already affected many species. First of all, human need to realize detailed fieldwork and should determine the endangered species. On the other hand, combination of the agreed methods should be implemented to evaluation of the current situation. Additionally, it is important to have information about the direct and indirect effects to climate and adaptation mechanisms of the species. That may be clear by focus on relations between species and environment, dynamics of landscape and population, combined effects of climatic changes.

\subsection{Agricultural Biodiversity and Sustainable Agriculture}

Agricultural activities (over tillage, fertilization, and pesticide use) pose the most important threats to natural bio-diversity. Plants are used today especially for health, nutrition, environmental protection and various industrial purposes. Insects in natural biodiversity interact with plants so that they can survive directly or indirectly. Thanks to this interaction, approximately $67 \%$ of the plant species are dependent on pollination by insects (Coleman, 2018). Following parts divided by insects and plants relationships with the topic.

\subsection{Importance of Insects in the Sustainable Agriculture and Environment}

Everyone especially farmers need to get the crucial value of insects to agriculture and food security. Insect and disease damage, when combined with climate change, is a big global challenge for a sustainable environment. Additionally, the key to sustainable agricultural production is the biodiversity of natural ecosystems which a fundamental trait more than any other human activity. Arthropods, for more than 400 million- year-exist, have been part of the ecosystem for $40 \%$ of biodiversity. Besides insects have had a wide range of vital ecological functions in their natural ecosystems, as herbivore, carnivore and feeding organic material (detritus), insects are commonly sensed as pests. However, their main ecological functions are ecological recycling, pollination, predation or parasitism, and being decomposers. If insects are guided in agricultural systems, they can take a role asfundamental instrumentation of the vital ecosystem (Coleman, 2018). And also insects are supported as an alternative protein source for human food, livestock and fish feed worldwide (Van Huis et al., 2013; Van Huis and Oonincx, 2017).

One of the cultivated areas and production of crops analysis indicated that the producers in the US have a permanent and significant need for all insect pollinators (honey bees, non-Apis pollinators etc.). And also that a reduction in managed or wild pollinator populations might be seriously threatenedby intensive agricultural systems of insect pollinated crops besides crops that are grown by seeds resulting from insect pollination (Calderone, 2012). The action of abiotic forces (wind, water etc.) can result from pollination which relies on animals, including bats, flies, butterflies, beetles and other insect (National, 2007; Coleman, 2018). The majority of insects pollinators are bees (Anthophila) (Grimaldi and Engel, 2005), of which there are approximately 17,000 defined species and as many as 30.000 species world-wide (Michener, 2000; National, 2007) whose (with rare exclusion) collect pollen and nectar from flowers. There is recently a renewing interest in the affecting health of honey bees and other insect pollinators (National, 2007), because of their pollination services that provide in both natural and agricultural ecosystems (Kearns and Inouye, 1997; 
Allen-Wardell et al., 1998; Kremen and Ricketts, 2000; Kevan and Viana, 2003; Gallai et al., 2009; Buchmann and Nabhan, 2012). It is believed that new practices for integrated management of both honey bees and diverse wild insect assemblage will improve universal crop yields in the world where have declined the diversity and abundance of wild insect pollinators (Garibaldi et al., 2013).

\subsection{Possible Influence of Climate Change on the Insects}

If we deal with the world's climate is changing at rates much faster than rates ever experienced before according to the last forecast, many ecosystems probably will not be able to settle for the change under these conditions (Houghton et al., 1990; Fleming and Volney, 1995). Nowadays there are a lot of statements about climate change on the Earth, the most famous theory is that average temperature will increase as a result of higher atmospheric $\mathrm{CO}_{2}$ concentration (Jaworski and Hilszczański, 2013). Therefore, the warming will probably lead to increased numbers of insect pests and also public health pests and insect vectored diseases too (Quarles, 2007). Also, climate changes are important for phytophagous insect species, and there are effective directly and indirectly basic climate parameters as temperature and humidity. According to researchers, (1) Polyphagous and eurytopic species have higher ecological plasticity and adapting abilities thanks to global warming. (2) The role of species especially thermophilous has currently increased and resulted in increased numbers and greater damage done by the pests. (3) Some phytophagous species status is changeable, can increase or decrease. For instance, the increased geographical range, increased numbers of generations, and higher densities are determined on some crop pests. (4) The number and the role of phytophagous species overwintering in egg stage have increased than in other development stages which have seen higher mortality at that time. (5) The dynamic of phytophagous insect population can affect by water shortage stress on plant. (6) The invasive phytophagous insect species can also increase because of climate change and absence of effective natural enemies in the new ecosystem (7) The changing of insect population is vital subscribers to cycling of nutrient and carbon, energy flowing, and decomposition of biomass (8) The relationship of pests and predators can have a profound effect like encourageable or not by temperature increases and parasitoid populations may also be exchanged by heavy status and variable climate (Haack and Byler, 1993; Parry, 1998; Stireman et al., 2005; Parmesan, 2006; Quarles, 2007; LaštůVka, 2009; Jaworski and Hilszczański, 2013). However, in most state the insect population growth is still indefinite whether the acceleration in development will be detrimental or not (Visser and Both, 2005).

\subsection{Importance of Plants in the Sustainable Agriculture and Environment}

Using of plants is as old as the history of humans. Health care purposeful plant based drugs are around 250 in Mesopotamia, 600 in Grecian and 4000 in Arabian Persian period (Baytop, 1999; Gencay, 2007). Today, traditional public drugs are becoming a science called as "ethnobotany" and this science deals with relations between plants and humans. The term "ethnobotany" was used by an American botanist John W. Harsberger in 1895 and the scientist published the first book in 1896 (Balick and Cox, 1996; Polat, 2010). Today, there has been limited study on ethnobotany still that is an essential need for sustainability of life by many advantages on bioconservation of species that were used by many people in ancient times for several purposes such as health care, food, building material, clothing, meadow-pasture and forage crop, fuel, biofuel, apiculture, sericulture, ornamental plant and landscape etc. basic needs besides economic development.

Global climate changes cause pressure on agriculture which tends to study drought stress and the response of plants by physiological and other growing statues etc. phenomena that the other climate change related projects (Kucukbasmaci and Sabir, 2019). Important notes are given under three points by NSAC (2019) as; policy recommendations about climate and agriculture, decreasing of greenhouse gases (GHG) emissions and knowledge transfer by focus on future generations. Additionally, promoting of family farms, opportunities for farming, equal opportunity for all races, fairness of farmworkers, farming systems providing sustainability of human welfare, environmental quality, controlling of biological cycles, economic feasibility, ecosystem owing to soil - water pollinator and wildlife health.

More than 1 billion people suffering worldwide which is equal to suffering over-nutrition, 155 million overweight or obese people, 148 million undernourished people while deaths worldwide every year 29 million due to overeating and 36 million due to lack of food. In another way, there are 1 billion cars while 2 billion people suffering from food access. Similarly, consumption of corn in the United States is around $390000 \mathrm{~m}^{3}$ annually while $55 \%$ is used as food and $45 \%$ is used for ethanol production for fuel. In the Worldwide, there are almost 3 billion farm animals while about $1 / 3$ of the total foods are used to feed these animals which means a serious effect on changes in climate (minimum $50 \%$ of the emissions welded by agriculture). Additionally, the demand for farm animals for water is 27.5 billion $\mathrm{m}^{3}$ in 2020 and estimated at around 45 billion $\mathrm{m}^{3}$ in 2050 . There are 4 highlights of the multidisciplinary reports for solving the concerns on the topic; food for all, food for sustainable growth, food for health and food for culture (Anonymous, 2021). 


\section{Conclusions}

Protection of nature is focused on species especially. Species are under effects of environmental factors that are mainly affected by climate and humans. Today, intensive pressure of human on the environment has been increased remarkably. The serious changes in human activities are considered as destructive effects on all living organisms in addition to natural resources. Climatic changes, biodiversity and other components of the earth are directly and indirectly connected while the main factor is human. So, human should pay attention to sustainability principles in all activities especially in agriculture. Therefore, there is a need to rising of awareness on sustainability of life and understanding the relations between human and nature that might be realized by education of nature for everyone.

\section{References}

Allen-Wardell G, Bernhardt P, Bitner R, Burquez A, Buchmann S, Cane J, Cox PA, Dalton V, Feinsinger P, Ingram M (1998). The potential consequences of pollinator declines on the conservation of biodiversity and stability of food crop yields, Conservation biology, 8-17.

Allison I, Bindoff N, Bindschadler R, Cox P, de Noblet N, England M, Francis J, Gruber N, Haywood A, Karoly D, Kaser G, Le Quéré C, Lenton TM, Mann ME, McNeil BI, Pitman AJ, Rahmstorf S, Rignot E, Schellnhuber HJ, Schneider SH, Sherwood SC, Somerville RCJ, Steffen K, Steig EJ, Visbeck M, Weaver AJ (2011). The Copenhagen Diagnosis: Updating the world on the latest climate science, The University of New South Wales Climate Change Research Centre (CCRC), Sydney, Australia, Elsevier, p. 60.

Anonymous (2021). Sustainable-Agriculture-Climate, https://www.barillacfn.com/m/publications/ppsustainable-agriculture-climate-changes.pdf [10.01.2021].

Balick MJ, Cox PA (1996). Plants, people, and culture: the science of ethnobotany, Scientific American Library.

Baytop T (1999). Therapy with medicinal plants in Turkey past and present, In, Eds, 2nd ed. , Nobel Tip Kitabevi, Istanbul.

Beton D (2011). Effects of climate change on biodiversity: A case study on four plant species using distribution models, Middle East Technical University, Ankara, Turkey., .

Blaustein AR, Walls SC, Bancroft BA, Lawler JJ, Searle CL, Gervasi SS (2010). Direct and indirect effects of climate change on amphibian populations, Diversity, 2 (2), 281-313.

Bosch J, Carrascal LM, Duran L, Walker S, Fisher MC (2007). Climate change and outbreaks of amphibian chytridiomycosis in a montane area of Central Spain; is there a link?, Proceedings of the Royal Society B: Biological Sciences, 274 (1607), 253260.

Brooks N (2004). Beyond collapse: the role of climatic desiccation in the emergence of complex societies in the middle Holocene, Environmental catastrophes in Mauritania, the Desert and the Coast, Abstract Volume and Field Guide. Mauritania, 4-18.

Buchmann SL, Nabhan GP (2012). The forgotten pollinators, Island Press, Shearwater Books, Washington, D.C.

Calderone NW (2012). Insect pollinated crops, insect pollinators and US agriculture: trend analysis of aggregate data for the period 1992-2009, PloS one, 7 (5), e37235.

Church JA, White NJ (2006). A 20th century acceleration in global sea-level rise, Geophysical research letters, 33 (1).

Coleman A (2018). Insects: the answer to sustainable agriculture: crops-insects and biodiversity, Farmer's Weekly, 2018 (18007), 44-46.

Çepel N (1997). Biyoçeşitlilik önemi ve korunması, Tema vakfı yayınları İstanbul.

Fleming RA, Volney WJA (1995). Effects of climate change on insect defoliator population processes in Canada's boreal forest: some plausible scenarios, Water, Air, and Soil Pollution, 82 (1-2), 445-454.

Gallai N, Salles J-M, Settele J, Vaissière BE (2009). Economic valuation of the vulnerability of world agriculture confronted with pollinator decline, Ecological economics, 68 (3), 810-821.

Garibaldi LA, Steffan-Dewenter I, Winfree R, Aizen MA, Bommarco R, Cunningham SA, Kremen C, Carvalheiro LG, Harder LD, Afik O (2013). Wild pollinators enhance fruit set of crops regardless of honey bee abundance, Science, 339 (6127), 16081611.

Gencay A (2007). Cizre'nin Etnobotanik özellikleri, Yüksek Lisans, Van Yüzüncüyll Üniversitesi Fen Bilimleri Enstitüsü, Biyoloji Anabilim Dalı.

Graham LE, Graham JM, Wilcox LW, Işık K (2004). Bitki biyolojisi, Palme Yayınları, p.

Grimaldi D, Engel MS (2005). Evolution of the Insects, Cambridge University Press, 155-187.

Haack RA, Byler JW (1993). INSECTS \& PATHOGENS Regulators of Forest Ecosystems, Journal of Forestry, 91 (9), 32-37.

Houghton JT, Jenkins GJ, Ephraums JJ (1990). Climate change: the IPCC scientific assessment, American Scientist;(United States), 80 (6).

Jaworski T, Hilszczański J (2013). The effect of temperature and humidity changes on insects development their impact on forest ecosystems in the expected climate change, Forest Research Papers, 74 (4), 345-355. 
Kearns CA, Inouye DW (1997). Pollinators, flowering plants, and conservation biology, Bioscience, 47 (5), 297-307.

Kevan PG, Viana BF (2003). The global decline of pollination services, Biodiversity, 4 (4), 3-8.

Kremen C, Ricketts T (2000). Global perspectives on pollination disruptions, Conservation biology, 14 (5), 1226-1228

Kucukbasmaci A, Sabir A (2019). Long-term impact of deficit irrigation on the physiology and growth of grapevine cv.'Prima'grafted on various rootstocks, Acta Scientiarum Polonorum. Hortorum Cultus, 18 (4).

LaštůVka Z (2009). Climate change and its possible influence on the occurrence and importance of insect pests, Plant Protection Science, 45 (Special Issue).

Levitus S, Antonov JI, Boyer TP, Locarnini RA, Garcia HE, Mishonov AV (2009). Global ocean heat content 1955-2008 in light of recently revealed instrumentation problems, Geophysical research letters, 36 (7).

Michener CD (2000). The bees of the world, Baltimore The John Hopkins University press.

NASA (2011). NASA National Aeronautics and Space Administration, https://www.nasa.gov/:

National RC (2007). Status of pollinators in North America, National Academies Press, p.

NOAA (2011). National Oceanic and Atmospheric Administration http://lwf.ncdc.noaa.gov/extremes/cei/index.html:

NSAC (2019). Agriculture and Climate Change: Policy Imperatives and Opportunities to Help Producers Meet the Challenge, Washington D.C.,

NSIDC (2011). The National Snow and Ice Data Center http://nsidc.org/sotc/glacier balance.html:

Parmesan C (2006). Ecological and evolutionary responses to recent climate change, Annu. Rev. Ecol. Evol. Syst., 37, 637-669.

Parry M (1998). The impact of climatic change on European agriculture.The Bawden Memorial Lectures 1973-98 (ed. T. Lewis), British Crop Protection Conference, Brighton, U.K, 325- 338.

Pidwirny M (2006). Biotic interactions and the distribution of species, Fundamentals of Physical Geography, p.

Pitlik SD (2020). COVID-19 Compared to Other Pandemic Diseases, Rambam Maimonides medical journal, 11 (3).

Polat R (2010). Havran ve Burhaniye (Balıkesir) çevresinde tarımsal biyoçeşitlilik ve etnobotanik araştırmaları.

Polyak L, Alley RB, Andrews JT, Brigham-Grette J, Cronin TM, Darby DA, Dyke AS, Fitzpatrick JJ, Funder S, Holland M (2010). History of sea ice in the Arctic, Quaternary Science Reviews, 29 (1516), 1757-1778.
Pounds JA, Bustamante MR, Coloma LA, Consuegra JA, Fogden MP, Foster PN, La Marca E, Masters KL, Merino-Viteri A, Puschendorf R (2006). Widespread amphibian extinctions from epidemic disease driven by global warming, Nature, 439 (7073), 161-167.

Quarles W (2007). Global warming means more pests, The IPM Practitioner, 29 (9/10), 1-8.

Ramaswamy V, Schwarzkopf M, Randel W, Santer B, Soden BJ, Stenchikov G (2006). Anthropogenic and natural influences in the evolution of lower stratospheric cooling, Science, 311 (5764), 11381141.

Sabine CL, Feely RA, Gruber N, Key RM, Lee K, Bullister JL, Wanninkhof R, Wong C, Wallace DW and Tilbrook B (2004). The oceanic sink for anthropogenic $\mathrm{CO}_{2}$, Science, 305 (5682), 367-371.

Sari H, Sari D, Eker T, Aydinoglu B, Canci H, Ikten C. Toker C (2020). Inheritance and expressivity of neoplasm trait in crosses between the domestic pea (Pisum sativum subsp. sativum) and Tall wild pea (Pisum sativum subsp. elatius), Agronomy, 10(12), 1869.

Schulze E, Mooney HA (1994). Biodiversity and Ecosystem Function, Biodiversity and ecosystem function. Springer, Berlin, Heidelberg, 497-510.

Solomon S, Qin D, Manning M, Chen Z, Marquis M, Averyt K, Tignor M, Miller H (2007). IPCC fourth assessment report (AR4), Climate change, 374.

Stireman J, Dyer LA, Janzen DH, Singer M, Lill J, Marquis RJ, Ricklefs RE, Gentry G, Hallwachs W, Coley PD (2005). Climatic unpredictability and parasitism of caterpillars: implications of global warming, Proceedings of the National Academy of Sciences, 102 (48), 17384-17387.

Toker C, Adak A, Sari D, Sari H, Ceylan FO, Canci H, Upadhyaya HD (2019). Registration of AWC 612M chickpea mutant germplasm line resistant to leaf miner (Liriomyza cicerina), Journal of Plant Registrations, 13(1), 87-90.

Van Huis A, Van Itterbeeck J, Klunder H, Mertens E, Halloran A, Muir G, Vantomme P (2013). Edible insects: future prospects for food and feed security, 171, Food and Agriculture Organization of the United Nations, p.

Van Huis A, Oonincx D (2017). The environmental sustainability of insects as food and feed. A review. Agron Sustain Dev 37: 43.

Velicogna I, Wahr J (2005). Greenland mass balance from GRACE, Geophysical research letters, 32 (18).

Visser ME, Both C (2005). Shifts in phenology due to global climate change: the need for a yardstick, Proceedings of the Royal Society B: Biological Sciences, 272 (1581), 2561-2569.

Wake DB (2007). Climate change implicated in amphibian and lizard declines, Proceedings of the 
Kahraman and Sahin Negis / Selcuk J Agr Food Sci, (2021) 35 (1), 65-70

National Academy of Sciences, 104 (20), 82018202.

WCMC (1992). Global biodiversity: Status of the earths living resources, In, Eds, Chapman and Hall, London, p. 594p.
WGMS

(2011).

http://www.geo.uzh.ch/microsite/wgms/:

WHO (2021). https://www.who.int/:

Williams T (2009). Climate change: Adaptation, Parliamentary Information and Research Service, Library of Parliment Canada, PRB 08 47E. 